\title{
Vitamin D and Adenosine Triphosphatase Dependent on Divalent Cations in Rat Intestinal Mucosa
}

\author{
Szloma Kowarski and David Schachter \\ From the Department of Physiology, Columbia University College of \\ Physicians and Surgeons, New York, New York 10032
}

A B S T R A C T Intestinal brush borders prepared from vitamin $\mathrm{D}$-deficient rats demonstrate increased susceptibility in vitro to fragmentation by shear forces or to loss of microvillus enzymes on treatment with EDTA. These effects are relatively nonspecific and are also observed in normal rats starved for $48 \mathrm{~h}$. They may underlie prior observations that purport to demonstrate a vitamin $\mathrm{D}$-dependent increase in brush border $\mathrm{Ca}$-dependent ATPase. In addition, however, vitamin D increases ATPase activity dependent on certain divalent cations, including $\mathrm{Ca}$ and $\mathrm{Zn}$, in whole-particulate suspensions pelleted by high-speed centrifugation of mucosal homogenates. This action is independent of changes in other microvillus enzymes, i.e. disaccharidases, and tissue distribution and cation specificity studies support the hypothesis that the mucosal whole-particulate ATPase is related to transport of $\mathrm{Ca}, \mathrm{Zn}$, and possibly other divalent cations.

\section{INTRODUCTION}

Vitamin D is essential for normal intestinal absorption of calcium, and a number of studies have contributed to an understanding of the cellular basis of its action (1$10)$. The sterol vitamin is metabolized to one or more hydroxylated products (5-7), which subsequently influence specific mechanisms of protein biosynthesis or turnover in the intestinal mucosal cell (8-10), thereby maintaining an active cation pump for calcium (1-4). The specific mucosal proteins regulated by vitamin $D$ are of considerable physiological significance as possibly representing parts of the pump mechanism itself. At least two kinds of mucosal proteins dependent on the vitamin have been described. A soluble, calcium-binding protein was first identified by Wasserman and Taylor (11) in homogenates of chicken mucosa, and a number of stud-

Received for publication 18 April 1973 and in recised form 9 July 1973. ies in various species provide evidence for a correlation between calcium transport and the quantity of the mucosal protein $(12,13)$. Subsequently, administration of vitamin $\mathrm{D}$ to deficient rats (14) and chickens (15) was shown to increase a calcium-dependent ATPase ( $\mathrm{Ca}$ ATPase $)^{1}$ activity in mucosal brush border preparations. Although this last observation has been confirmed, its specificity remains unclear because other microvillus enzymes, e.g., leucine aminopeptidase (16) and disaccharidases (see below) are also observed to increase simultaneously. The present studies were undertaken to clarify the significance of the vitamin D-dependent mucosal ATPase with regard to cation transport.

The experiments to be described define two distinct actions of vitamin $\mathrm{D}$ on mucosal particulate membranes and enzymes of the rat. The first action is relatively nonspecific and results in increased resistance of brush borders in vitro to fragmentation by shear forces or to treatment with EDTA. Thus, in the preparation of brush borders (17) from rats deficient in vitamin $\mathrm{D}$, the microvillus membranes lose disproportionate amounts of disaccharidase and other enzymes and cannot be compared meaningfully with corresponding preparations from vitamin-repleted animals. This action of vitamin D may well underlie the prior observations concerning CaATPase (14-16). A second action of vitamin D, however, is a more specific increase in mucosal ATPase dependent on certain divalent cations, including $\mathrm{Ca}$ and $\mathrm{Zn}$. This increment is demonstrable in the total particulate obtained on high-speed centrifugation of mucosal homogenates and occurs with no change in disaccharidase activity.

\section{METHODS}

Animals and dicts. Normal rats, albino males of the Sherman strain, 110-130 g, were maintained on a complete pellet diet (Camm Research Institute, Inc., Wayne, N. J.)

${ }^{1}$ Abbreviations used in this paper: CaATPase, ATPase dependent on $\mathrm{Ca}$.

The Journal of Clinical Investigation Volume 52 November 1973·2765-2773 
plus water ad libitum. In vitamin D-depletion studies weanling male rats of the same strain, $45-50 \mathrm{~g}$, were maintained on the U.S.P. Rachitogenic Diet No. 2 (Nutritional Biochemical Corporation, Cleveland, Ohio) for 4-5 wk and housed in cages shielded from light, as previously described (3). Groups of deficient rats were repleted by subcutaneous injection of 10,000 IU of vitamin $D_{3}$ (ViDe-3-Hydrosol, Wander, S. A., Berne, Switzerland) at least $4 \mathrm{~h}$ before death. All animals were starved $18 \mathrm{~h}$ in metabolism cages before removal of the intestine.

Whole-particulate and brush border preparations. Groups of 5-7 rats were killed by decapitation, and the appropriate intestinal segments were removed, slit lengthwise, rinsed in ice-cold $145 \mathrm{mM} \mathrm{NaCl}-4 \mathrm{mM} \mathrm{KCl}$, and the mucosa scraped off with a glass slide. All subsequent operations were at $2-5^{\circ} \mathrm{C}$. Pooled mucosa was homogenized for $25 \mathrm{~s}$ in a VirTis homogenizer (VirTis Co., Inc., Gardiner, N. Y.) at an intermediate speed (dial setting 70) in 75 vol of $5 \mathrm{mM}$ sodium EDTA of $\mathrm{pH}$ 7.4. The resulting suspension was filtered through silk (Joymar Scientific Inc., Hockville, N. Y.) to yield the crude homogenate. Portions of the homogenate were used to prepare the whole-particulate and brush border fractions. Whole-particulate was sedimented by centrifugation at $105,000 \mathrm{~g}$ for $1 \mathrm{~h}$ in a Spinco model L2 ultracentrifuge (Beckman Instruments, Inc., Spinco Div. Palo Alto, Calif.). The pellet was washed once with $12 \mathrm{ml}$ of the sodium EDTA, recentrifuged as described above, and suspended finally in $3 \mathrm{ml}$ of $2.5 \mathrm{mM}$ Tris-EDTA of $\mathrm{pH}$ 7.4. Suspensions of brush borders were prepared by the method of Forstner, Sabesin, and Isselbacher (17). The crude homogenate was centrifuged at $450 \mathrm{~g}$ for $10 \mathrm{~min}$ in an International refrigerated centrifuge (International Equipment Company, Needham Heights, Mass.), the pellet washed four times by resuspension in 5 vol of the $5 \mathrm{mM} \mathrm{Na}$ EDTA, and the washed pellet suspended finally in 15 vol of $90 \mathrm{mM} \mathrm{NaCl}$ containing $0.8 \mathrm{mM}$ $\mathrm{Na}$ EDTA of $\mathrm{pH}$ 7.4. The suspension stood at $2^{\circ} \mathrm{C}$ for $20 \mathrm{~min}$ and was then filtered through glass wool (Pyrex brand, Corning No. 3950, Corning Glass Works, Science Products Div., Corning, N. Y.). The glass wool was washed with $20 \mathrm{ml} \mathrm{Na}$ EDTA of $\mathrm{pH} \mathrm{7.4,} \mathrm{the} \mathrm{filtrate} \mathrm{and} \mathrm{washes}$ were combined, the whole spun in the International centrifuge at $450 \mathrm{~g}$ for $10 \mathrm{~min}$, and the pellet containing the brush borders suspended in $2.5-5.0 \mathrm{ml}$ of $2.5 \mathrm{mM}$ TrisEDTA of $\mathrm{pH} 7.4$ for assays. The brush border content of these suspensions was quantified either by counting in a Petroff-Hausser chamber, with a Zeiss phase-contrast microscope (Carl Zeiss, Inc., New York), or by chemical estimation of the total protein content (18). Both methods of quantification gave similar results, i.e., agreed within $12 \%$ when used to compare preparations from normal, vitamin D-depleted, and vitamin D-repleted rats, and the base adopted routinely for enzyme assays was the protein content.

Enzyme assays. All assays were in duplicate. ATPase was estimated by quantifying released inorganic phosphate $\left(P_{1}\right)$. The $1.0-\mathrm{ml}$ reaction mixture contained $40 \mathrm{mM}$ Tris hydrochloride of $\mathrm{pH} 7.4,5 \mathrm{mM}$ Tris-ATP (Sigma Chemical Co., St. Louis, Mo.) of $\mathrm{pH} 7.4$, sufficient brush border suspension to provide $20 \mu \mathrm{g}$ of protein and, where appropriate, $\mathrm{CaCl}_{2}, \mathrm{MgCl}_{2}$, or both. Unless indicated otherwise, the final concentrations were $2.0 \mathrm{mM} \mathrm{CaCl} \mathrm{Ca}_{2}$ and $1.0 \mathrm{mM}$ $\mathrm{MgCl}_{2}$. The Tris-ATP was purified before use by passage over a column of Dowex $50 \mathrm{~W}-\mathrm{X} 8$ cation exchange resin (Dow Chemical Co., Midland, Mich.) to remove traces of cations. Appropriate controls containing either no added suspension, no ATP, or no cation were tested with each batch. The mixtures were shaken for $30 \mathrm{~min}$ at $37^{\circ} \mathrm{C}$, the reactions terminated by addition of cold trichloracetic acid to a final concentration of $5 \%$, and $\mathrm{Pi}$ in the protein-free supernatant solutions estimated by the method of Gomori (19). Cation-dependent ATPase activity was calculated as the increment in $P_{1}$ owing to the presence of the appropriate cation and expressed in units of micromoles per minutemilligram of protein.

Sucrase and maltase activities were estimated by the method of Dahlqvist (20). The glucose liberated in these reactions was assayed by a glucose oxidase method (21), using Glucostat Special reagents (Worthington Biochemical Corp., Freehold, N. J.). Alkaline phosphatase activities were determined in a reaction mixture containing $6 \mathrm{mM}$ $p$-nitrophenyl phosphate (Sigma Chemical Co.) as substrate, $50 \mathrm{mM}$ glycine buffer of $\mathrm{pH} 10.5$, and $5 \mathrm{mM} \mathrm{MgCl}_{2}$. In appropriate experiments the glycine buffer was replaced with $50 \mathrm{mM}$ Tris of $\mathrm{pH} 7.4$.

\section{RESULTS}

Vitamin D and brush border ATPase and disaccharidase. Groups of vitamin D-deficient rats were repleted (Methods), and after 4 or $24 \mathrm{~h}$ the proximal duodenal segments of repleted and deficient animals were removed and mucosal homogenates and brush border suspensions prepared. Table I summarizes the results of estimations of brush border ATPase dependent on $\mathrm{Ca}$ and $\mathrm{Mg}$, and Table II shows the corresponding values for disaccharidase levels in homogenates and brush borders. Vitamin D significantly increased the CaATPase observed at both 4 $\mathrm{h}(P<0.01)$ and $24 \mathrm{~h}(P<0.001)$, with relative increments of $45.8 \%$ and $29.0 \%$, respectively. No significant effect was observed on MgATPase at either time and the ratio CaATPase/MgATPase was thus increased significantly. Table $\mathrm{I}$ lists an additional parameter, $\triangle \mathrm{Ca}$ ATPase/MgATPase, defined as $\left[\left(P_{1}\right.\right.$ liberated with 2 $\mathrm{mM}$ Ca plus $1 \mathrm{mM} \mathrm{Mg})-\left(\mathrm{P}_{1}\right.$ liberated with $1 \mathrm{mM} \mathrm{Mg}$ ] $\div\left(P_{1}\right.$ liberated with $\left.1 \mathrm{mM} \mathrm{Mg}\right)$, and noted to be a sensitive index of the vitamin's action (see below). Vitamin D increased this parameter by $79.7 \%(P<0.01)$ and $75.5 \%(P<0.01)$ at 4 and $24 \mathrm{~h}$, respectively.

Corresponding to its effects on brush border ATPase, vitamin $\mathrm{D}$ increased brush border sucrase by $74 \%(P<$ $0.02)$ after $24 \mathrm{~h}$. However, no significant change in sucrase activity of the crude homogenate was observed (Table II). Thus the values for relative purification of brush border sucrase, i.e., (brush border sucrase activity)/(homogenate sucrase activity) were 2.54 vs. 4.57 ( $P<$ 0.01 ) for vitamin-deficient versus repleted rats. At $4 \mathrm{~h}$ after the vitamin mean values for brush border sucrase and maltase activity, as well as for relative purification of the disaccharidases, were in each instance higher for repleted rats, but the individual differences were not statistically significant in these experiments. The results suggested that vitamin D treatment, notably after $24 \mathrm{~h}$, influences the structure of the brush border and protects it from loss of enzymes during the isolation pro- 


\section{TABLE'I}

Effects of Vitamin D on CaATPase and MgATPase in Brush Border Suspensions Prepared from Rat Duodenal Mucosa*

\begin{tabular}{|c|c|c|c|c|c|c|}
\hline \multirow[b]{2}{*}{$\begin{array}{c}\text { Time } \\
\text { after } \\
\text { Vitamin D }\end{array}$} & \multirow[b]{2}{*}{$\begin{array}{r}\text { No. of } \\
\text { exps }\end{array}$} & \multirow[b]{2}{*}{ Group } & \multicolumn{2}{|c|}{ ATPase activity } & \multirow[b]{2}{*}{$\begin{array}{c}\text { Ratio } \\
\text { a/b }\end{array}$} & \multirow[b]{2}{*}{$\begin{array}{l}\triangle \mathrm{CaATPase} / \\
\text { MgATPASE }\end{array}$} \\
\hline & & & $\begin{array}{l}\text { CaATPase } \\
\text { (a) }\end{array}$ & $\begin{array}{l}\text { MgATPase } \\
\text { (b) }\end{array}$ & & \\
\hline$h$ & \multicolumn{6}{|c|}{$\mu m o l P_{1} / \min -m g$} \\
\hline \multirow[t]{4}{*}{4} & 7 & - vit. D & 0.24 & 0.18 & 1.50 & 0.64 \\
\hline & & + vit. D & 0.35 & 0.19 & 2.08 & 1.15 \\
\hline & & $P$ & $<0.01$ & $\mathrm{NS}$ & $<0.01$ & $<0.01$ \\
\hline & & SE & 0.02 & 0.01 & 0.16 & 0.12 \\
\hline \multirow[t]{4}{*}{24} & 6 & - vit. D & 0.31 & 0.23 & 1.35 & 0.49 \\
\hline & & + vit. D & 0.40 & 0.22 & 1.84 & 0.86 \\
\hline & & $P$ & $<0.001$ & NS & $<0.01$ & $<0.01$ \\
\hline & & $\mathrm{SE}$ & 0.01 & 0.01 & 0.11 & 0.09 \\
\hline
\end{tabular}

* Brush borders were prepared as described (Methods) and tested for ATPase in the presence or absence of $2 \mathrm{mM} \mathrm{CaCl}_{2}$ or $1 \mathrm{mM} \mathrm{MgCl}_{2}$. $\triangle \mathrm{CaATPase} \div \mathrm{MgATPase}$ is defined in the text. SE and $P$ values are computed from $t$ tests of paired differences. † Seven depleted and repleted rats were killed in each experiment and the duodenal mucosal scrapings pooled to prepare the brush border suspensions.

cedure. Evidence favoring this hypothesis is presented below.

Vitamin $D$ and recovery of brush border proteins. During the preparation of brush border pellets (Methods) it became apparent that vitamin-deficient rats yielded consistently smaller pellets than did repleted animals, although the weights of duodenal mucosal starting material were similar. Table III summarizes the results of 12 experiments in which recoveries of brush borders were quantified by estimation of total protein. After vitamin $D$ the mean values for recovery of brush border proteins were increased by $64 \%$ and $38 \%$, respectively, at $4 \mathrm{~h}(P<0.05)$ and $24 \mathrm{~h}(P<0.01)$. These results were confirmed by brush border counts determined in a Petroff-Hausser counting chamber.

Experiments were then designed to test the effects of the speed and duration of homogenization, i.e., the shear force applied to the mucosa, on the recovery of brush borders from depleted and treated rats, and the results of three experiments are summarized in Table IV. Three levels of shear force, the intermediate condition representing our usual procedure, were examined. With in-

TABLE II

Effects of Vitamin D on Disaccharidase Activities of Duodenal Mucosal Homogenates and Brush Border Suspensions*

\begin{tabular}{|c|c|c|c|c|c|c|c|}
\hline \multirow[b]{2}{*}{$\begin{array}{c}\text { Time } \\
\text { after } \\
\text { vitamin D }\end{array}$} & \multirow[b]{2}{*}{ Group } & \multicolumn{2}{|c|}{ Sucrase zctivity } & \multirow[b]{2}{*}{$\begin{array}{l}\text { Ratio } \\
\text { b/a }\end{array}$} & \multicolumn{2}{|c|}{ Maltase activity } & \multirow[b]{2}{*}{$\begin{array}{l}\text { Ratio } \\
\text { d/c }\end{array}$} \\
\hline & & $\begin{array}{l}\text { Homog- } \\
\text { enate } \\
\text { (a) }\end{array}$ & $\begin{array}{l}\text { Brush } \\
\text { border } \\
\text { (b) }\end{array}$ & & $\begin{array}{l}\text { Homog- } \\
\text { enate } \\
\text { (c) }\end{array}$ & $\begin{array}{l}\text { Brush } \\
\text { border } \\
\text { (d) }\end{array}$ & \\
\hline$h$ & & \multicolumn{2}{|c|}{$\mu \mathrm{mol} / \mathrm{min}-\mathrm{g}$} & & \multicolumn{2}{|c|}{$\mu \mathrm{mol} / \mathrm{min}-\mathrm{g}$} & \\
\hline \multirow{4}{*}{4} & - vit. D & 0.87 & 2.75 & 3.9 & 6.32 & 29.3 & 5.2 \\
\hline & + vit. D & 0.77 & 3.40 & 5.2 & 6.67 & 42.0 & 7.4 \\
\hline & $P$ & NS & NS & NS & NS & NS & NS \\
\hline & $\mathrm{SE}$ & 0.06 & 0.41 & 1.41 & 0.65 & 7.27 & 1.2 \\
\hline \multirow[t]{4}{*}{24} & - vit. D & 1.75 & 4.65 & 2.54 & & & \\
\hline & + vit. $\mathrm{D}$ & 1.78 & 8.07 & 4.57 & & & \\
\hline & $P$ & NS & $<0.02$ & $<0.01$ & & & \\
\hline & $\mathrm{SE}$ & 0.05 & 1.00 & 0.53 & & & \\
\hline
\end{tabular}

* Values are for the same experimental groups described in Table I. SE and $P$ values are for paired differences \pm vitamin D. 
TABLE III

Effects of Vitamin D on Recovery of Brush Borders Prepared from Duodenal Mucosal Homogenates*

\begin{tabular}{|c|c|c|c|c|c|}
\hline \multirow[b]{2}{*}{$\begin{array}{l}\text { Time } \\
\text { after } \\
\text { vit. D }\end{array}$} & \multirow[b]{2}{*}{$\begin{array}{c}\text { No. of } \\
\text { exps }\end{array}$} & \multirow[b]{2}{*}{ Group } & \multicolumn{2}{|c|}{ Total protein, mean values } & \multirow[b]{2}{*}{ (b) $/(a)$} \\
\hline & & & $\begin{array}{l}\text { Homog- } \\
\text { enate } \\
\text { (a) }\end{array}$ & $\begin{array}{l}\text { Brush } \\
\text { Borders } \\
\text { (b) }\end{array}$ & \\
\hline$h$ & & & \multicolumn{2}{|c|}{$m g$} & $\%$ \\
\hline \multirow[t]{4}{*}{4} & 8 & - vit. D & 117 & 1.27 & 1.09 \\
\hline & & + vit. D & 120 & 2.08 & 1.72 \\
\hline & & $P$ & NS & $<0.05$ & $<0.05$ \\
\hline & & $\mathrm{SE}$ & & 0.40 & 0.30 \\
\hline \multirow[t]{4}{*}{24} & 4 & - vit. D & 117 & 0.78 & 0.68 \\
\hline & & + vit. $\mathrm{D}$ & 116 & 1.27 & 1.10 \\
\hline & & $P$ & NS & $<0.01$ & $<0.02$ \\
\hline & & SE & & 0.04 & 0.11 \\
\hline
\end{tabular}

* In each experiment seven depleted and repleted rats were killed and their mucosa pooled as for the experiments in Table I SE and $P$ values are for paired differences \pm vitamin $D$. All animals were starved immediately after vitamin $\mathrm{D}$ repletion.

creasing force the recovery of brush border proteins decreased in both the deficient and treated groups, but relatively less force was effective in the deficient group. At the lowest level tested the recovery of brush border proteins was $62 \%$ greater for treated as compared to untreated rats. The difference was accentuated at the next higher level, i.e., $171 \%$ greater for treated as compared to untreated animals. As shown in Table IV, the preceding increase in shear force lowered the respective recoveries in the deficient and repleted groups by $43 \%$ vs. $6 \%$. At the highest force level tested the recovery in the repleted group was also decreased, approaching that for deficient rats. The foregoing effects are not unique to vitamin $\mathrm{D}$ deficiency and were observed in two experiments with normal rats starved for $48 \mathrm{~h}$ in metabolism cages (Table IV). After starvation, the recoveries of brush borders decreased markedly with increasing shear force, whereas rats fed ad libitum showed no consistent reduction. It is noteworthy that the effects of vitamin $\mathrm{D}$ described above are independent of food intake, inasmuch as all the rats were starved from the time of repletion. Table IV also lists values for the sucrase and maltase activity ratios (brush borders/whole particulate) observed in the preceding experiments. No consistent effect of shear force on the ratios was observed, but at any particular shear force the values for vitamin D-treated and for fed rats were consistently greater than those for the corresponding deficient or starved animals. This suggested that other steps in the peparation of the brush borders might account for the disproportionate losses of disaccharidase activities, and assays were performed to identify these steps. Brush border

TABLE IV

Effects of Vitamin D or Starvation on Recovery of Brush Borders Prepared from Duodenal Mucosal Homogenates*

\begin{tabular}{|c|c|c|c|c|c|c|}
\hline \multirow[b]{2}{*}{$\begin{array}{l}\text { No. of } \\
\text { exps. }\end{array}$} & \multirow[b]{2}{*}{ Group } & \multicolumn{2}{|c|}{ Homogenization } & \multirow{2}{*}{$\begin{array}{c}\text { Recovery of } \\
\text { particulate } \\
\text { protein in } \\
\text { brush borders }\end{array}$} & \multirow{2}{*}{$\begin{array}{c}\text { Sucrase } \\
\text { activity } \\
\text { ratio } \\
\text { (brush border/ } \\
\text { particulate) }\end{array}$} & \multirow{2}{*}{$\begin{array}{c}\text { Maltase } \\
\text { activity } \\
\text { ratio } \\
\text { (brush border/ } \\
\text { particulate) }\end{array}$} \\
\hline & & $\begin{array}{l}\text { Speed } \\
\text { setting }\end{array}$ & Time & & & \\
\hline & & & $s$ & $\%$ & & \\
\hline \multirow[t]{6}{*}{3} & - vit. D & 10 & 10 & 8.5 & 2.1 & 2.3 \\
\hline & & 70 & 25 & 4.8 & 1.3 & 1.4 \\
\hline & & 100 & 90 & 4.2 & 1.6 & 2.3 \\
\hline & + vit. D & 10 & 10 & 13.8 & 4.6 & 3.5 \\
\hline & & 70 & 25 & 13.0 & 2.8 & 2.1 \\
\hline & & 100 & 90 & 5.4 & 2.3 & 2.9 \\
\hline \multirow[t]{6}{*}{2} & starved $\ddagger$ & 10 & 10 & 6.4 & 4.0 & 3.1 \\
\hline & & 70 & 25 & 1.4 & 2.8 & 4.8 \\
\hline & & 100 & 90 & 1.2 & 2.5 & 4.0 \\
\hline & fed & 10 & 10 & 3.8 & 9.3 & 16.3 \\
\hline & & 70 & 25 & 6.4 & 6.3 & 8.2 \\
\hline & & 100 & 90 & 5.7 & 9.1 & 10.8 \\
\hline
\end{tabular}

* Seven vitamin-deficient and -repleted rats were killed for each experiment and mucosal scrapings were pooled. "Particulate" refers to whole-particulate suspensions (Methods). Speed settings are for increasingly rapid rates of homogenization in a VirTis homogenizer. All rats were starved immediately after vitamin repletion at $18 \mathrm{~h}$ before the experiment. Mean values are shown.

‡ Starved rats were maintained on water alone for $48 \mathrm{~h}$ in metabolism cages. Seven starved and fed rats were used and duodenal mucosal scrapings pooled in each experiment. Mean values are shown. 
TABLE V

Effects of Vitamin D or Starvation on Recovery of Brush Borders Prepared from Duodenal Mucosal Homogenates*

\begin{tabular}{|c|c|c|c|c|c|}
\hline \multirow{2}{*}{$\begin{array}{l}\text { No. } \\
\text { of } \\
\text { exps. }\end{array}$} & \multirow[b]{2}{*}{ Fraction } & \multicolumn{2}{|c|}{ Sucrase activity } & \multicolumn{2}{|c|}{ Maltase activity } \\
\hline & & - vit. D & + vit. D & - vit. D & + vit. D \\
\hline & & \multicolumn{2}{|c|}{$\mu \mathrm{mol} / \mathrm{min}-\mathrm{g}$} & \multicolumn{2}{|c|}{$\mu \mathrm{mol} / \mathrm{min}-\mathrm{g}$} \\
\hline \multirow[t]{7}{*}{3} & Homogenate & 0.85 & 0.84 & 3.53 & 3.40 \\
\hline & Pellet $\ddagger$ from: & & & & \\
\hline & first supernate & 0.28 & 0.27 & 2.67 & 3.03 \\
\hline & washes $(\times 3)$ & 2.50 & 0.85 & 17.0 & 9.00 \\
\hline & final supernatant & 1.90 & 1.12 & 18.5 & 15.6 \\
\hline & Brush borders & 3.58 & 6.34 & 28.5 & 44.2 \\
\hline & & fasted & fed & & \\
\hline \multirow[t]{6}{*}{2} & Homogenate & 0.29 & 0.34 & & \\
\hline & Pellet $\ddagger$ from: & & & & \\
\hline & first supernate & 0.09 & 0.13 & & \\
\hline & washes $(\times 3)$ & 1.04 & 0.57 & & \\
\hline & final supernatant & 0.81 & 2.25 & & \\
\hline & Brush borders & 0.83 & 2.80 & & \\
\hline
\end{tabular}

* In each experiment seven vitamin-deficient and -treated rats were killed and duodenal mucosal scrapings pooled. Starved animals were maintained for $48 \mathrm{~h}$ in metabolism cages on water alone. Vitamin D-deficient and -repleted rats were starved immediately after the vitamin treatment given 18 $\mathrm{h}$ before the experiment. Mean values are listed.

$\ddagger$ Pellet refers to that precipitated on high-speed centrifugation $(105,000 \mathrm{~g}$, $1 \mathrm{~h}$ ). The bulk of the total enzyme activity recovered was in the "washes $\times 3$ " fraction. In the starved-fed experiments the final supernate contained only $8-11 \%$ of the sucrase activity lost from the brush borders, and the major losses were recovered in the washes $\times 3$. Hence the starved preparations showed a greater over-all loss as compared to fed preparations.

suspensions from vitamin D-deficient and repleted rats or from starved and fed animals were prepared (Methods), except that after the brush borders were pelleted at low speed $(450 \mathrm{~g}, 10 \mathrm{~min})$ the supernatant fluid at each step was removed, centrifuged at high speed $(105,000 \mathrm{~g}, 1 \mathrm{~h})$, and the resulting high-speed pellets also assayed for disaccharidase activity. The results in Table $\mathrm{V}$ demonstrate again that vitamin $\mathrm{D}$ does not influence the disaccharidase activity of the total mucosal homogenate. When the brush border pellets were washed with $5 \mathrm{mM}$ NaEDTA of pH 7.4, however, vitamin-deficient preparations lost three times as much sucrase activity and twice as much maltase activity to the supernatant solutions. Because of these losses the final brush border suspensions from vitamin-deficient animals contained considerably less disaccharidase as compared to repleted animals. Similar disproportionate losses of sucrase were observed when preparations from starved as compared to fed rats were washed with the EDTA (Table V). In summary, the foregoing experiments indicate that vitamin $\mathrm{D}$ decreases the susceptibility of brush borders to fragmentation by shear forces in vitro or to loss of their enzymes on treatment with EDTA. Normal food intake acts similarly, although the effects of vitamin $D$ were demonstrated in starving animals and are independent of feeding. Additional observations in the three experiments listed in Table $\mathrm{V}$ demonstrated that other brush border enzymes, notably CaATPase and leucine aminopeptidase, were also lost disproportionately from the vitamin-deficient preparations. The values for $\triangle \mathrm{CaATPase} / \mathrm{MgATPase}$ in the final brush border suspensions from vitamin-deficient as compared to repleted rats were 0.53 (range 0.35-0.88) and 1.00 (range $0.54-1.26$ ), respectively. In contrast, the high-speed pellets obtained from the supernatant EDTA washes showed a reverse relationship, with values of 0.63 (range $0.20-0.89$ ) and 0.39 (range $0-0.58$ ), respectively, for deficient and repleted animals. Thus it seemed advisable to study whole-particulate preparations of mucosa. Unlike the brush border preparations, whole particulate suspensions from vitamin-deficient and repleted rats have been shown repeatedly to contain equal amounts of disaccharidase activity.

ATPase in whole-particulate preparations. The effects of vitamin $\mathrm{D}$ on $\mathrm{Ca}$ - and $\mathrm{MgATPase}$ in whole-particulate preparations of duodenal mucosa (Methods) were examined in 11 experiments, and the results are shown in Fig. 1. CaATPase was increased by $29 \%(P<0.01)$, whereas MgATPase was not significantly affected. The ratio $\mathrm{CaATPase} / \mathrm{MgATP}$ ase was increased by $47 \%$ $(P<0.001)$ and $\Delta$ CaATPase $/$ MgATPase by $59 \%(P<$ $0.005)$.

To study the effects of various concentrations of $\mathrm{Ca}$ and $\mathrm{Mg}$ on the CaATPase activity, whole-particulate preparations from four separate groups of vitamin D-deficient and repleted rats were examined. The results illustrated in Fig. 2 (vitamin-deficient) and Fig. 3 (repleted) are qual-

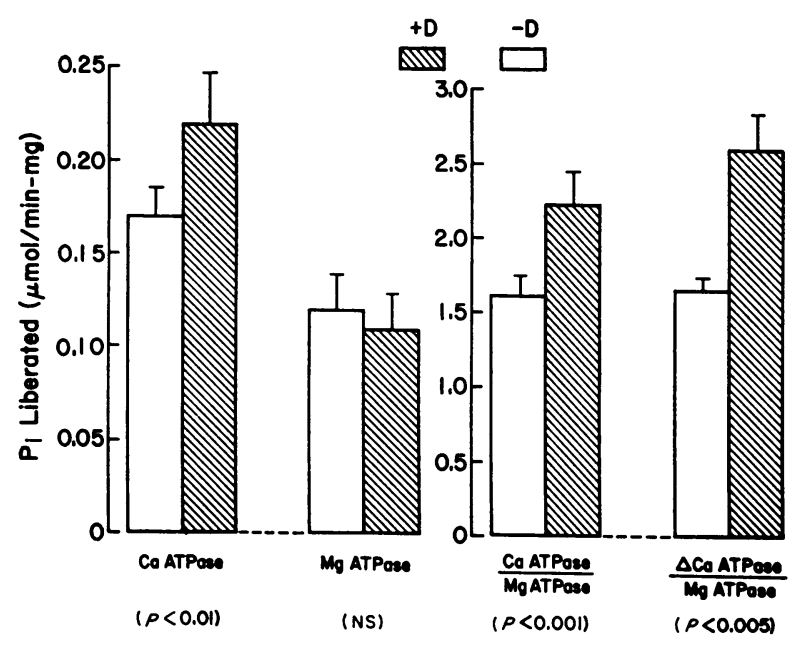

FIGURE 1 Effects of vitamin D on ATPase activities of whole-particulate suspensions of rat duodenal mucosa. Mean values \pm SE are shown for 11 experiments with deficient (light bars) and repleted (dark bars) rats. In each experiment seven deficient and repleted animals were killed and mucosal scrapings pooled. $P$ values shown are for paired differences \pm vitamin $D$. Vitamin $D$ was administered $24 \mathrm{~h}$ before the experiment and all rats were starved after the repletion. 


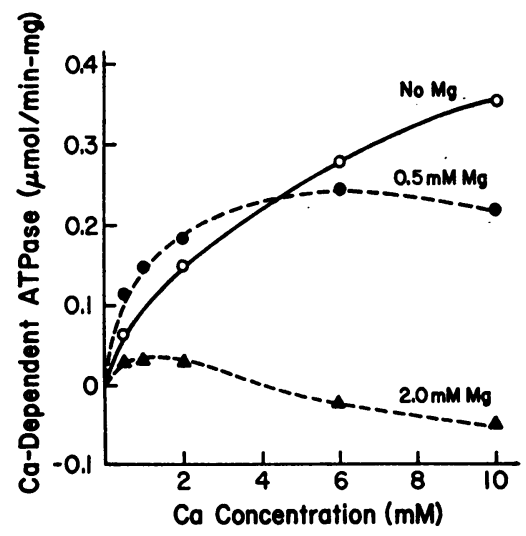

Figure 2 CaATPase activity as a function of $\mathrm{Ca}$ and $\mathrm{Mg}$ concentration in whole-particulate suspensions prepared from duodenal mucosa of vitamin D-deficient rats. Mean values for four experiments are plotted; each experiment utilized seven deficient and repleted rats. Negative values in the presence of $2.0 \mathrm{mM} \mathrm{Mg}$ indicate that addition of $\mathrm{Ca}$ decreases $P_{1}$ release from ATP below that observed with the $\mathrm{Mg}$ alone.

itatively similar. In the absence of added $\mathrm{Mg}$, release of $P_{1}$ as a function of $\mathrm{Ca}$ concentration from $0.5-10 \mathrm{mM}$ follows Michaelis-Menten kinetics, and values for $V_{m}$ and $K_{m}$, determined from double reciprocal plots (22), are listed in Table VI. Vitamin D increased $V_{m}$ by $30 \%$ $(P<0.01) ; K_{m}$ did not change significantly in this small series. Repetition of the studies in the presence of 0.5 $\mathrm{mM} \mathrm{Mg}$ markedly altered the kinetics in both the vitamin-depleted and repleted preparations. $P_{1}$ release was increased at low concentrations $(0.5-2.0 \mathrm{mM})$ and decreased at higher $\mathrm{Ca}$ concentrations $(6-10 \mathrm{mM})$. Further, addition of $\mathrm{Ca}$ in excess of $6 \mathrm{mM}$ was inhibitory. Addition of $0.5 \mathrm{mM} \mathrm{Mg}$ markedly decreased the $K_{m}$ for $\mathrm{Ca}$ (Table VI) from a mean value of $4.9 \mathrm{mM}$ to $0.6 \mathrm{mM}$ $(P<0.01)$ in the repleted preparations; corresponding

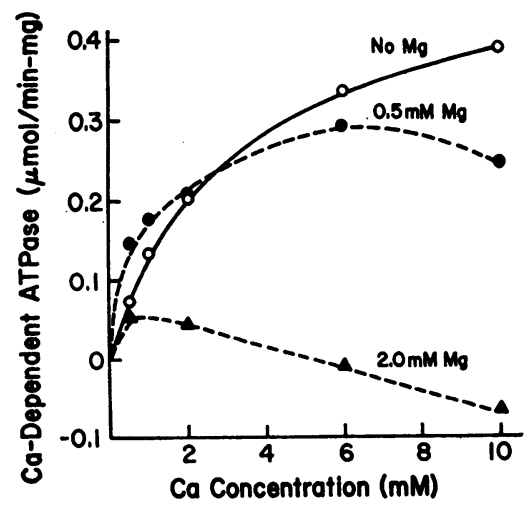

Figure 3 CaATPase activity as a function of $\mathrm{Ca}$ and $\mathrm{Mg}$ concentration in whole-particulate suspensions from vitamin D-repleted rats. Data plotted are for the experiments described in Fig. 2.
TABLE VI

CaATPase Activity in Whole-Particulate Suspensions of

Duodenal Mucosa: Kinetic Parameters of $P_{i}$ Release with Increasing Ca Concentration*

\begin{tabular}{lccc}
\hline Cation & Group & $\begin{array}{c}\text { Vm, mean } \\
\text { (range) }\end{array}$ & $\begin{array}{c}K_{m}, \text { mean } \\
\text { (range) }\end{array}$ \\
\hline \multirow{3}{*}{$\mathrm{Ca}$} & & $\mu m o l / m i n-m g$ & $m M$ \\
& - vit. D & $0.43(0.26-0.67)$ & $2.7(1.3-2.9)$ \\
Ca plus & $P$ & $<0.01(0.40-0.84)$ & $4.9(2.9-8.3)$ \\
Mg $(0.5 \mathrm{mM})$ & - vit. D & $0.34(0.22-0.48)$ & $0.7(0.2-1.3)$ \\
& + vit. D & $0.36(0.28-0.46)$ & $0.6(0.1-1.0)$ \\
& $P$ & NS & NS
\end{tabular}

* Values for four experiments are listed. Seven deficient rats, repleted $18 \mathrm{~h}$ before the experiment, were killed and mucosal scrapings pooled in each experiment. $P$ values shown are for paired differences \pm vitamin D. $K_{m}$ values in the presence of $0.5 \mathrm{mM} \mathrm{Mg}$ are significantly lower than in its absence, as indicated in the text $(P<0.01)$.

values for depleted preparations were $2.7 \mathrm{mM}$ and 0.7 $\mathrm{mM}(P<0.01)$. Figs. 2 and 3 also illustrate that in the presence of $2 \mathrm{mM} \mathrm{Mg}$ release of total $P_{1}$ was inhibited by $1-10 \mathrm{mM} \mathrm{Ca}$ in both deficient and repleted preparations. The results are interpreted in terms of an enzyme complex with several regulatory sites in the Discussion.

ATPase and intestinal transport. Experiments were designed to evaluate the relationship of the vitamin D-dependent ATPase to $\mathrm{Ca}$ transport. Evidence to date has established only one organ in the rat, the small intestine, as capable of vitamin D-dependent $\mathrm{Ca}$ transport, and a number of organs were therefore screened to search for CaATPase dependent on vitamin D. Groups of seven vitamin-depleted and repleted rats were killed, and wholeparticulate suspensions (Methods) were prepared from various tissues and tested for $\mathrm{Ca}$ - and $\mathrm{MgATPase}$. Although both ATPases were present in each preparation, no significant increment with vitamin $\mathrm{D}$ was observed in either CaATPase or CaATPase/MgATPase with each of the following (the number of experiments is indicated in parenthesis): kidney $(n-7)$, liver $(n-4)$, tibial metaphysis $(n-7)$, cranial bone $(n-2)$, skeletal muscle $(n-2)$, spleen $(n-2)$, testes $(n-2)$, or brain $(n-2)$.

Within the small intestine $\mathrm{Ca}$ transport is maximal in the duodenum just distal to the pylorus and decreases in more distal segments (2-4). Accordingly, brush border ATPase and disaccharidase activities were assayed in three sequential segments, respectively, 0-6, 6-12, and $12-18 \mathrm{~cm}$ from the pylorus. Mucosa from five normal rats was pooled for each preparation, and Fig. 4 illustrates the results of six experiments. Values for brush border CaATPase, MgATPase, and $\triangle \mathrm{CaATPase} / \mathrm{MgATPase}$ were highest in the most proximal segment and decreased in the distal segments (respective $P$ values were $<0.02$, $<0.05$, and $<0.01$ ). In contrast, brush border sucrase and maltase activities were greatest in the most distal 
segment tested $(P<0.01)$. The results were not influenced by disproportionate losses of microvillus enzymes in vitro, inasmuch as the values for relative purification [i.e., ratios of disaccharidase activity (brush border/ crude homogenate)] were similar for the proximal and most distal segments : 6.7 vs. 6.4 for sucrase, and 9.8 vs. 9.5 for maltase. Distribution of the brush border CaATPase in the upper small intestine thus conforms to that of the Ca transport mechanism (1-3).

Additional evidence has been obtained from studies of the cation specificity of mucosal ATPase dependent on vitamin $\mathrm{D}$. Whole-particulate suspensions were prepared from the duodenal mucosa of seven vitamin-depleted and repleted rats and tested for ATPase activity (Methods) in the absence and presence of $1 \mathrm{mM}$ divalent cation. Vitamin D increased CaATPase by $50 \mathrm{nmol} / \mathrm{min}-\mathrm{mg}$, and the corresponding increments observed, respectively, with $\mathrm{Zn}, \mathrm{Mg}, \mathrm{Mn}$, and Co were $83,61,49$, and 51 . The relatively large effect observed with $Z_{n}$ was investigated further in two experiments with whole-particulate suspensions by determining the kinetics of $P_{1}$ release as a function of $\mathrm{Zn}$ concentration. The $K_{m}$ values for $\mathrm{Zn}$ observed with vitamin $D$-deficient versus repleted suspensions were, respectively, $1.2-1.3 \mathrm{mM}$ vs. $0.5-0.8 \mathrm{mM}$; corresponding values for $V_{m}(\mu \mathrm{mol} / \mathrm{min}-\mathrm{mg})$ were, respectively, $0.39-0.45$ vs. $0.48-0.49$. The results demonstrate a mucosal $\mathrm{ZnATPase}$ activity influenced by vitamin D. Given the hypothesis that mucosal ATPase activity is related to cation transport, it was reasonable to predict the existence of a vitamin D-dependent $\mathrm{Zn}$ transfer mechanism in intestinal mucosa, and considerable experimental evidence supporting this prediction was obtained thereafter $(23)^{2}$ as discussed further below.

- Particulate alkaline phosphatase. Several investigators $(24,25)$ have reported that vitamin $\mathrm{D}$ increases brush border alkaline phosphatase and CaATPase simultaneously in chick intestinal mucosa, suggesting that both activities reside in a single enzyme complex. Inasmuch as the former studies utilized brush borders, it was of interest to examine the effects of vitamin D on wholeparticulate as well as brush border suspensions prepared from rats. In 12 observations with six groups of vitamindepleted and repleted rats, increases in CaATPase and alkaline phosphatase were correlated positively in both whole-particulate and brush border suspensions $(r=$ $0.66, P=0.02$ ). In addition, the possibility that ATP can competitively inhibit the alkaline phosphatase substrate, p-nitrophenyl phosphate, was examined with two whole-particulate suspensions prepared from duodenal mucosa. The assay for alkaline phosphatase (Methods)

\footnotetext{
${ }^{2}$ Kowarski, S., C. S. Blair-Stanek, and D. Schachter. 1973. Active transport of zinc and identification of zincbinding protein in rat jejunal mucosa. Submitted for publication.
}

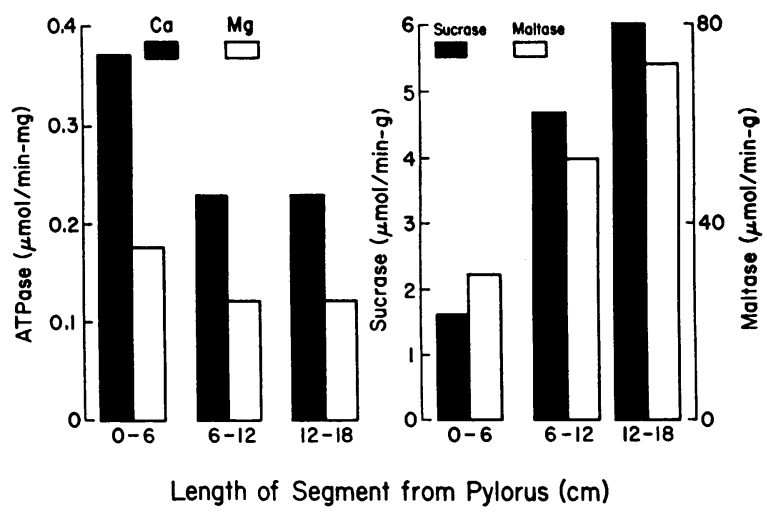

FIgURE 4 Brush border enzymatic activities as a function of the segment of intestine. Results of six experiments are plotted. In each experiment five normal rats (110-115 g body wt) were killed and mucosal scrapings from the appropriate segments pooled. For ATPase activities the values obtained for the $0-6-\mathrm{cm}$ segments were compared with those for the $6-18-\mathrm{cm}$ segments by $t$ tests. For disaccharidases the 0-6-cm segments were compared with the 12-18-cm segments. Decreases in CaATPase ( $\mathrm{SE}=$ $0.05, P<0.02)$ and MgATPase $(\mathrm{SE}=0.025, P<0.05)$ with sequential segments contrast with increases in sucrase $(\mathrm{SE}=0.04, P<0.01)$ and maltase $(\mathrm{SE}=0.27, P<0.01)$.

was modified in that $40 \mathrm{mM}$ Tris buffer of $\mathrm{pH} 7.4$ replaced the glycine buffer of higher $\mathrm{pH}$, and all reaction mixtures contained $2 \mathrm{mM} \mathrm{CaCl}$. Hydrolysis at $37^{\circ} \mathrm{C}$ was estimated at various concentrations of $p$-nitrophenyl phosphate in the presence or absence of $2 \mathrm{mM}$ ATP, and the results were plotted by the method of Lineweaver and Burk (22). Plots typical of competitive inhibition were observed in each experiment with $K_{\text {i }}$ values for ATP of 0.6 and $1.4 \mathrm{mM}$. The results support the possibility of a single enzyme complex with both activities in rat duodenal mucosa. In view of this, it is noteworthy that Holdsworth (24) concluded that such an enzyme could not be involved in Ca transport across chick mucosa, inasmuch as phenylalanine, an inhibitor of alkaline phosphatase and CaATPase, did not inhibit $\mathrm{Ca}$ transfer in vitro. This evidence, however, is not conclusive, because $\mathrm{Ca}$ transfer was tested at $\mathrm{pH} 7.4$ whereas the inhibition of the enzyme activities by phenylalanine was observed at $\mathrm{pH} 8.5$ (24). On testing wholeparticulate suspensions prepared from rat duodenum we observed that $20 \mathrm{mM}$ L-phenylanine inhibited the hydrolysis of $p$-nitrophenyl phosphate at $\mathrm{pH} 8.5$ by $64 \%$, whereas the corresponding inhibition at $\mathrm{pH} 7.4$ was only $6.4 \%$.

\section{DISCUSSION}

The foregoing results demonstrate that vitamin $\mathrm{D}$ deficiency in rats produces both general and specific changes in the membranes of intestinal mucosal cells. The general changes consist of increased susceptibility of the 
brush borders to fragmentation by shear forces in vitro and loss of microvillus enzymes on treatment with EDTA. These membrane changes are not necessarily related to the specific action of vitamin $\mathrm{D}$ on $\mathrm{Ca}$ absorption, and they are also observed with preparations from starved rats that transport $\mathrm{Ca}$ normally. Prior studies (14-16, 24, 25) that describe decreases in brush border CaATPase owing to vitamin D deficiency should be reinterpreted in the light of the present findings.

A more specific effect of vitamin $\mathrm{D}$ was demonstrated on ATPase dependent on divalent cations, notably $\mathrm{Ca}$ and $\mathrm{Zn}$, in whole-particulate suspensions of intestinal mucosa. The physiologically important question of whether the mucosal CaATPase is an integral part of the vitamin D-dependent calcium pump has not been answered definitively, but several lines of evidence favor such a relationship. Tissue distribution studies indicate that CaATPase dependent on vitamin D is observed only in the mucosa of the small intestine and is greatest in the most proximal segment of the duodenum, in accord with the localization of the calcium transport mechanism (2-4). Moreover, from the general hypothesis that vitamin D-dependent mucosal ATPase is related to cation transport, we predicted that the observed $\mathrm{ZnATP}$ ase was involved in a $\mathrm{Zn}$ transfer mechanism dependent on vitamin $\mathrm{D}$. Subsequently, the predicted $\mathrm{Zn}$ transfer mechanism was observed in rat intestinal segments in vitro $(23) .^{2}$ The transport has been characterized further as a net transfer in the direction of secretion (serosa to mucosa) against electrochemical potential gradients, and, like $\mathrm{Ca}$ transport, it is associated with a soluble $\mathrm{Zn}$ binding protein that has been purified partially from jejunal mucosal homogenates. ${ }^{2}$ Thus for $\mathrm{Ca}$ and $\mathrm{Zn}$ there exist in the small intestine separate active transport mechanisms, each of which is associated with a soluble binding protein and a particulate ATPase activity.

Prior evidence indicates that the active transport of $\mathrm{Ca}$ from the mucosal surface involves at least two distinct steps, entry into and exit from the mucosal cell $(3,4)$, and both steps are dependent on vitamin D. A simple working model incorporating the present results is that the binding protein is responsible for one of the steps, perhaps the exit, as previously suggested (26), whereas the ATPase is essential for the other. The intracellular localization of CaATPase activity related to $\mathrm{Ca}$ transport has not been defined in the present studies. However, the experiments with sequential intestinal segments from normal rats (Fig. 4) suggest that the brush border may be one such site. If so, it is reasonable to propose that the ATPase participates in the entry process. Clearly the present evidence does not exclude other models.

Irrespective of the precise model, it is worth emphasizing that one or another of the steps in a multistage process may become rate-limiting under different con- ditions. If, for example, the $\mathrm{Ca}$-binding protein and $\mathrm{Ca}$ ATPase are responsible for different steps, their respective concentrations in the mucosa will correlate with $\mathrm{Ca}$ transport only when the appropriate step is ratelimiting. Thus the many positive correlations between the Ca-binding protein and $\mathrm{Ca}$ transport $(12,13)$ carry more weight than the relatively few instances in which the correlation was not found $(4,15)$. The latter may signify merely that a different step was rate-limiting.

The vitamin D-dependent ATPases described in this report are activated by a number of divalent cations. Further studies are needed to determine the number of individual enzymes involved and their respective cation specificities and localization in cellular organelles. A preliminary indication of significant relationships between cations is given in the CaATPase experiments summarized in Figs. 2 and 3 and Table VI. Magnesium $(0.5 \mathrm{mM})$ increased markedly the affinity of the mucosal ATPase for $\mathrm{Ca}$, as indicated by the approximately fourand eightfold differences in $K_{m}$ observed, respectively, with vitamin-deficient and repleted particulates (Table $\mathrm{VI})$. At higher concentrations of $\mathrm{Mg}$ two additional effects became evident: (a) progressive reduction of the Ca-dependent moiety of total $P_{1}$ release, ascribable to competition between the cations; and (b) Ca-dependent inhibition of the ATPase. The results are explicable in terms of a single enzyme containing three sites: $(a)$ an "affinity" site with specificity for $\mathrm{Mg}$; occupation of this site increases the affinity for $\mathrm{Ca}$ of the remaining two sites; (b) an "activating" site with specificity for $\mathrm{Ca}$ or $\mathrm{Mg}$ and the locus of the competition between them; and $(c)$ an "inhibitor" site with specificity for Ca when $\mathrm{Mg}$ occupies the affinity locus. These relationships suggest that $\mathrm{Mg}$ may have a physiologically significant role in regulating mucosal CaATPase activity.

\section{ACKNOWLEDGMENTS}

This research was supported by research grants AM-01483 and AM- 04407 from the National Institutes of Health (NIAMDD) and by the Irma T. Hirschl Trust.

\section{REFERENCES}

1. Schachter, D., and S. M. Rosen. 1959. Active transport of $\mathrm{Ca}^{45}$ by the small intestine and its dependence on vitamin D. Am. J. Physiol. 196: 357.

2. Dowdle, E. B., D. Schachter, and H. Schenker. 1960. Requirement for vitamin D for the active transport of calcium by the intestine. Am. J. Physiol. 198: 269.

3. Schachter, D., D. V. Kimberg, and H. Schenker. 1961. Active transport of calcium by intestine: action and bio-assay of vitamin D. Am. J. Physiol. 200: 1263.

4. Schachter, D., S. Kowarski, and P. Reid. 1969. Active transport of calcium by intestine: studies with a calcium activity electrode. In A Symposium on Calcium and Cellular Function. A. W. Cuthbert, editor. Macmillan \& Co., Ltd., London. 108-123.

\section{S. Kowarski and D. Schachter}


5. Blunt, J. W. H. F. DeLuca, and H. K. Schnoes. 1968. 25-Hydroxycholecalciferol: a biologically active metabolite of vitamin $\mathrm{D}_{3}$. Biochemistry. $7: 3317$.

6. Holick, M. F., H. K. Schnoes, and H. F. DeLuca. 1971. Identification of 1,25-dihydroxycholecalciferol, a form of vitamin $\mathrm{D}_{\mathbf{8}}$ metabolically active in the intestine. Proc. Natl. Acad. Sci. U. S. A. 68: 803.

7. Iawson, D. E. M., D. R. Fraser, E. Kodicek, H. R. Morris, and D. H. Williams. 1971. Identification of 1,25dihydroxycholecalciferol, a new kidney hormone controlling calcium metabolism. Nature (Lond.). 230: 228.

8. Schachter, D., and S. Kowarski. 1965. Radioactive vitamin D: preparation, metabolism and mechanism of action. Bull. N. Y. Acad. Med. 41: 241.

9. Zull, J. E., E. Czarnowski-Misztal, and H. F. DeLuca. 1965. Actinomycin D inhibition of vitamin D action. Science (Wash., D. C.). 149: 182.

10. Norman, A. W. 1965. Actinomycin D and the response to vitamin D. Science (Wash., D. C.). 149: 184.

11. Wasserman, R. H., and A. N. Taylor. 1966. Vitamin $D_{3^{-}}$ induced calcium-binding protein in chick intestinal $\mathrm{mu}$ cosa. Science (Wash., D. C.). 152: 791.

12. Wasserman, R. H., and A. N. Taylor. 1968. Vitamin Ddependent calcium-binding protein: response to some physiological and nutritional variables. J. Biol. Chem. $243: 3987$.

13. Schachter, D., S. Kowarski, and P. Reid. 1967. Molecular basis for vitamin $\mathrm{D}$ action in the small intestine. J. Clin. Invest. 46: 1113a. (Abstr.)

14. Martin, D. L., M. J. Melancon, Jr., and H. F. DeLuca. 1969. Vitamin D stimulated, calcium-dependent adenosine triphosphatase from brush borders of rat small intestine. Biochem. Biophys. Res. Comm. 35: 819

15. Melancon, M. J., Jr., and H. F. Deluca. 1970. Vitamin D stimulation of calcium-dependent adenosine triphospha- tase in chick intestinal brush borders. Biochemistry. 9: 1658.

16. Taylor, A. N., and R. H. Wasserman. 1970. Vitamin L stimulation of calcium-binding protein and brush border enzyme activities. Fed. Proc. 29: 368a.

17. Forstner, G. G., S. M. Sabesin, and K. J. Isselbacher. 1968. Rat intestinal microvillus membranes. Purification and biochemical characterization. Biochem. J. 106: 381 .

18. Lowry, O. H.. N. J. Rosebrough, A. L. Farr, and R. J. Randall. 1961. Protein measurement with the Folin phenol reagent. J. Biol. Chem. 193: 265.

19. Gomori, G. 1942. A modification of the colorimetric phosphorus determination for use with the photoelectric colorimeter. J. Lab. Clin. Mcd. 27: 955.

20. Dahlquist, A. 1964. Method for assay of intestinal disaccharidases. Anal. Biochem. $7: 18$.

21. Washko, M. E., and E. W. Rice. 1961. Determination of glucose by an improved "glucostat" procedure. Clin. Chem. 7: 542 .

22. Lineweaver, H., and D. Burk. 1934. The determination of enzyme dissociation constants. J. Am. Chem. Soc. 56: 658 .

23. Schachter, D., and S. Kowarski. 1972. Vitamin D and the intestinal transport of zinc. J. Clin. Invest. 283: 86a. (Abstr.)

24. Holdsworth, E. S. 1970. The effect of vitamin D on enzyme activities in the mucosal cells of the chick small intestine. J. Membrane Biol. 3: 43.

25. Haussler, M. R., L. A. Nagode, and H. Rasmussen. 1970. Induction of intestinal brush border alkaline phosphatase by vitamin D and identity with Ca-ATPase. Nature (Lond.). 228: 1199.

26. Schachter, D. 1969. Toward a molecular description of active transport. In Biological Membranes. R. M. Dowben, editor. Little, Brown \& Co., Inc., Boston. 157. 